\title{
Facilitation of Conditioned Fear Extinction by Systemic Administration or Intra-Amygdala Infusions of D-Cycloserine as Assessed with Fear-Potentiated Startle in Rats
}

\author{
David L. Walker, Kerry J. Ressler, Kwok-Tung Lu, and Michael Davis \\ Department of Psychiatry and Behavioral Sciences, Emory University, Atlanta, Georgia 30322
}

NMDA receptor antagonists block conditioned fear extinction when injected systemically and also when infused directly into the amygdala. Here we evaluate the ability of D-cycloserine (DCS), a partial agonist at the strychnine-insensitive glycinerecognition site on the NMDA receptor complex, to facilitate conditioned fear extinction after systemic administration or intra-amygdala infusions.

Rats received 10 pairings of a $3.7 \mathrm{sec}$ light and a $0.4 \mathrm{~mA}$ footshock (fear conditioning). Fear-potentiated startle (increased startle in the presence vs the absence of the light) was subsequently measured before and after 30,60 , or 90 presentations of the light without shock (extinction training). Thirty non-reinforced light presentations produced modest extinction, and 60 or 90 presentations produced nearly complete extinction (experiment 1). DCS injections $(3.25,15$, or $30 \mathrm{mg} / \mathrm{kg}$ ) before 30 non-reinforced light exposures dose-dependently enhanced extinction (experiment 2) but did not influence fearpotentiated startle in rats that did not receive extinction training (experiment 3). These effects were blocked by HA-966, an antagonist at the glycine-recognition site (experiment 4). Neither DCS nor HA-966 altered fear-potentiated startle when injected before testing (experiment 5). The effect of systemic administration was mimicked by intra-amygdala DCS $(10 \mu \mathrm{g} /$ side) infusions (experiment 6).

These results indicate that treatments that promote NMDA receptor activity after either systemic or intra-amygdala administration promote the extinction of conditioned fear.

Key words: D-cycloserine; HA-966; NMDA; fear conditioning; fear-potentiated startle; extinction; amygdala
Classical fear conditioning occurs when an affectively neutral stimulus is paired with a noxious aversive stimulus [unconditioned stimulus (US)] such as footshock. Afterward, the previously neutral stimulus [i.e., now the conditioned stimulus (CS)] is able to elicit a variety of autonomic, hormonal, and skeletal responses that accompany the conscious experience of fear in humans and that are used to operationally define fear in laboratory animals. The fear-eliciting properties of the CS can be extinguished by repeatedly presenting the CS in the absence of the US. It is generally believed that extinction does not reflect unlearning of the original association but involves instead the formation of new associations that compete with the previously conditioned response (cf. Bouton and Bolles, 1985; Falls and Davis, 1995; Davis et al., 2000; Rescorla, 2001). As with fear conditioning itself, fear extinction can be blocked by NMDA receptor antagonists administered either systemically (Cox and Westbrook, 1994; Baker and Azorlosa, 1996) or infused directly into the amygdala (Falls et al., 1992; Lee and Kim, 1998). The involvement of the amygdala is of particular interest given the well known involvement of this structure in excitatory fear conditioning (Kapp et al., 1990; Fanselow and LeDoux, 1999; Davis, 2000).

Received Oct. 11, 2001; revised Dec. 18, 2001; accepted Dec. 19, 2001.

This work was supported by National Institute of Mental Health Grants MH 47840, MH 57250, MH 58922, MH 52384, and MH 59906; by the Woodruff Foundation; by the Science and Technology Center Program (The Center for Behavioral Neuroscience) of the National Science Foundation under Agreement No. IBN-9876754; and by a Pfizer Postdoctoral Fellowship Award (K.J.R.).

Correspondence should be addressed to David L. Walker, Emory University School of Medicine, Department of Psychiatry and Behavioral Sciences, 1639 Pierce Drive, Suite 4000, Atlanta, GA 30322. E-mail: dlwalke@emory.edu.

Copyright (C) 2002 Society for Neuroscience $0270-6474 / 02 / 222343-09 \$ 15.00 / 0$
Because NMDA receptor antagonists block extinction, it is possible that NMDA receptor agonists would facilitate extinction. However, the well documented neurotoxic effects of NMDA receptor agonists argue against their use in humans and, as such, increasing attention has focused on partial agonists that might facilitate NMDA receptor activity in a more limited manner (Lawlor and Davis, 1992; Olney, 1994). In fact, partial agonists such as D-cycloserine (DCS), a compound that acts at the strychnine-insensitive glycine-recognition site of the NMDA receptor complex, have been shown to enhance learning and memory in several animal paradigms, including visual recognition tasks in primates (Matsuoka and Aigner, 1996), eyeblink conditioning in rabbits (Thompson et al., 1992), avoidance learning in rats and mice (Monahan et al., 1989; Flood et al., 1992; Land and Riccio, 1999), and maze learning in rats and mice (Monahan et al., 1989; Quartermain et al., 1994; Pitkanen et al., 1995; Pussinen et al., 1997), without producing obvious neurotoxicity. DCS has also been found, in some studies, to modestly improve cognition in clinical populations (Javitt et al., 1994; Schwartz et al., 1996; Goff et al., 1999; Tsai et al., 1999) and has been used for many years to treat tuberculosis, again without obvious neurotoxicity.

Because a reduced ability to extinguish intense fear memories is a significant clinical problem (e.g., in specific phobias, panic disorder, and post-traumatic stress disorder) (Morgan et al., 1995; Fyer, 1998; Gorman et al., 2000) and because treatment for these disorders often relies on the progressive extinction of fear memories (Zarate and Agras, 1994; Dadds et al., 1997; Foa, 2000), pharmacological enhancement of extinction could be of considerable clinical benefit. With this in mind, we sought to determine whether conditioned fear extinction could be enhanced by DCS. 


\section{MATERIALS AND METHODS}

\section{Animals}

Adult male Sprague Dawley rats (Charles River, Raleigh, NC) weighing between 300 and $400 \mathrm{gm}$ were used. Animals were housed in group cages of four rats each in a temperature-controlled $\left(24^{\circ} \mathrm{C}\right)$ animal colony, with access to food and water ad libitum. They were maintained on a $12 \mathrm{hr}$ light/dark cycle with lights on at 7:00 A.M. All behavioral procedures took place during the rats' light cycle. A total of 178 rats were used.

\section{Apparatus}

Animals were trained and tested in $8 \times 15 \times 15 \mathrm{~cm}$ Plexiglas and wire-mesh cages. The cage floor consisted of four 6.0 -mm-diameter stainless-steel bars spaced $18 \mathrm{~mm}$ apart. Each cage was suspended between compression springs within a steel frame and located within a custom-designed $90 \times 70 \times 70 \mathrm{~cm}$ ventilated sound-attenuating chamber. Background noise ( $60 \mathrm{~dB}$ wide-band) was provided by a General Radio Type 1390-B noise generator (Concord, MA) and delivered through high-frequency speakers (Radio Shack Supertweeter; Tandy, Fort Worth, TX) located $5 \mathrm{~cm}$ from the front of each cage. Sound level measurements (sound pressure level) were made with a Bruel \& Kjaer (Marlborough, MA) model 2235 sound-level meter (A scale; random input) with the microphone (Type 4176) located $7 \mathrm{~cm}$ from the center of the speaker (approximating the distance of the rat's ear from the speaker).

Startle responses were evoked by $50 \mathrm{msec}, 95 \mathrm{~dB}$ white-noise bursts $(5$ msec rise-decay) generated by a Macintosh G3 computer soundfile (0-22 $\mathrm{kHz}$ ), amplified by a Radio Shack amplifier (100 W; model MPA-200; Tandy), and delivered through the same speakers used to provide background noise. An accelerometer (model U321AO2; PCB Piezotronics, Depew, NY) affixed to the bottom of each cage produced a voltage output proportional to the velocity of cage movement. This output was amplified (model 483B21; PCB Piezotronics) and digitized on a scale of $0-2500 \mathrm{U}$ by an InstruNET device (model 100B; GW Instruments, Somerville, MA) interfaced to a Macintosh G3 computer. Startle amplitude was defined as the maximal peak-to-peak voltage that occurred during the first $200 \mathrm{msec}$ after onset of the startle-eliciting stimulus.

The CS was a $3.7 \mathrm{sec}$ light ( 82 lux) produced by an $8 \mathrm{~W}$ fluorescent bulb (100 $\mu \mathrm{sec}$ rise time) located $10 \mathrm{~cm}$ behind each cage. Luminosity was measured using a VWR light meter (Atlanta, GA). The US was a $0.5 \mathrm{sec}$ shock, delivered to the floorbars and produced by a shock generator (SGS-004; LeHigh Valley, Beltsville, MD). Shock intensities (measured as in Cassella et al., 1986) were $0.4 \mathrm{~mA}$. The presentation and sequencing of all stimuli were under the control of the Macintosh G3 computer using custom-designed software (The Experimenter; Glassbeads Inc., Newton, CT).

\section{Surgery and histology}

Rats that were to receive intra-amygdala infusions (experiment 6) were anesthetized with Nembutal (50 mg/kg sodium pentobarbital, i.p) and placed in a stereotaxic frame (ASI Instruments, Inc., Warren, MI). The skull was exposed and 22 gauge guide cannulas (model C313G; Plastics One, Inc., Roanoke, VA) were implanted bilaterally into the basolateral nucleus of the amygdala (anteroposterior, -2.8; dorsoventral, -9.0; mediolateral, \pm 5.0 from bregma). Dummy cannulas (model C313DC; Plastics One, Inc.) were inserted into each cannula to prevent clogging. These extended $\sim 1 \mathrm{~mm}$ past the end of the guide cannula. Screws were anchored to the skull and the assembly was cemented in place using dental cement (The Hygenic Corp., Akron, OH).

Behavioral procedures began either 10 or $11 \mathrm{~d}$ after surgery. Cannulated rats subsequently received a chloral hydrate overdose and were perfused intracardially with $0.9 \%$ saline followed by $10 \%$ formalin. The brains were removed and immersed in a 30\% sucrose-formalin solution for at least $3 \mathrm{~d}$, after which $40 \mu \mathrm{m}$ coronal sections were cut through the area of interest. Every fourth section was mounted and stained with cresyl violet.

\section{Drug administration}

Systemic administration. D-cycloserine (Sigma-Aldrich, St. Louis, MO) $(3.25,15$, and $30 \mathrm{mg} / \mathrm{kg}$ ) and ( \pm )-HA-966 (Research Biochemicals, Inc., Natick, MA) $(6 \mathrm{mg} / \mathrm{kg})$ were freshly dissolved in saline and injected intraperitoneally $30 \mathrm{~min}$ before extinction training. Drug doses were chosen based on preliminary findings (K. T. Lu and M. Davis, unpublished results), on the results of other behavioral studies (Monahan et al., 1989; Flood et al., 1992; Moraes Ferreira and Morato, 1997; Pussinen et al., 1997; Land and Riccio, 1999), on estimates of brain concentration after systemic administration (extrapolated from Loscher et al., 1994)
A

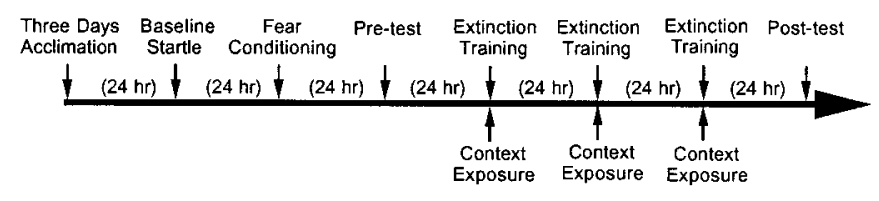

B

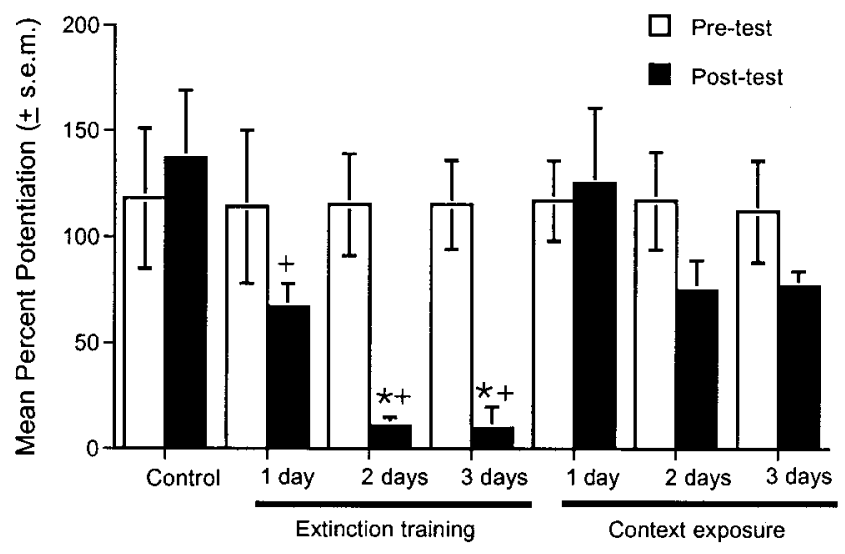

Treatment

Figure 1. Parametric evaluation of different amounts of extinction training. $A$, Timeline of the behavioral procedures for experiment $1 . B$. Percent fear-potentiated startle measured $24 \mathrm{hr}$ before (pretest) and $24 \mathrm{hr}$ after (post-test) extinction training or context exposure. The control group was tested $2 \mathrm{~d}$ after the pretest, with no intervening exposures. One session of non-reinforced cue exposure produced only modest levels of extinction. Two or three sessions more completely extinguished the fear response. ${ }^{*} p<0.05$ versus context exposure group; ${ }^{+} p<0.05$ versus control group.

together with findings relating drug concentrations in vitro to DCS effects on NMDA receptor function measured electrophysiologically (Watson et al., 1990; Priestley and Kemp, 1994) or vis-à-vis ligand binding to the use-dependent channel-associated binding site (Hood et al., 1989; Hamelin and Lehmann, 1995), and on the ability of systemically administered DCS to influence NMDA receptor-mediated cGMP concentrations in mouse cerebellum (Emmett et al., 1991).

Intra-amygdala infusion. DCS (10 $\mu \mathrm{g} / \mathrm{side})$ or saline was infused $(0.25$ $\mu \mathrm{l} / \mathrm{min}$ ) through 28 gauge injection cannulas (model C313I; Plastic Products) $20 \mathrm{~min}$ before extinction training. The total volume inf used was 0.5 $\mu \mathrm{l} /$ side. The infusion cannulas were left in place for $2 \mathrm{~min}$ before being withdrawn.

\section{General behavioral procedures}

Behavioral procedures for all experiments consisted of an acclimation phase, a baseline startle test, a fear-conditioning phase, a pre-extinction test, extinction training, and a postextinction test (Fig. $1 A$ ).

Acclimation. On each of 3 consecutive days, rats were placed into the test chambers for $10 \mathrm{~min}$ and then returned to their home cages.

Baseline startle test. On each of the next 2 consecutive days, animals were placed in the test chambers and presented with $3095 \mathrm{~dB}$ noise bursts at a $30 \mathrm{sec}$ interstimulus interval (ISI). Animals whose baseline startle was $<1 \%$ of the possible accelerometer output were excluded insofar as fear-potentiated startle cannot be properly measured with such a low baseline ( 2 of 144 rats were excluded on this basis).

Fear conditioning. After $24 \mathrm{hr}$, rats were returned to the test chambers and $5 \mathrm{~min}$ later given the first of 10 light-footshock pairings. The $0.4 \mathrm{~mA}$, $0.5 \mathrm{sec}$ shock was delivered during the last $0.5 \mathrm{sec}$ of the $3.7 \mathrm{sec}$ light. The average intertrial interval was 4 min (range, 3-5 min).

Pre-extinction test. At $24 \mathrm{hr}$ after fear conditioning, rats were returned to the test chambers and presented 5 min later with $3095 \mathrm{~dB}$ noise bursts ( $30 \mathrm{sec}$ ISI). These initial startle stimuli were used to habituate the startle response to a stable baseline before the noise-alone and light-noise test trials that followed. A stable baseline, in turn, reduces variability in the 


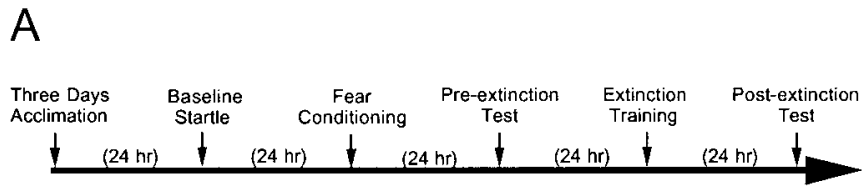

$\mathrm{B}$

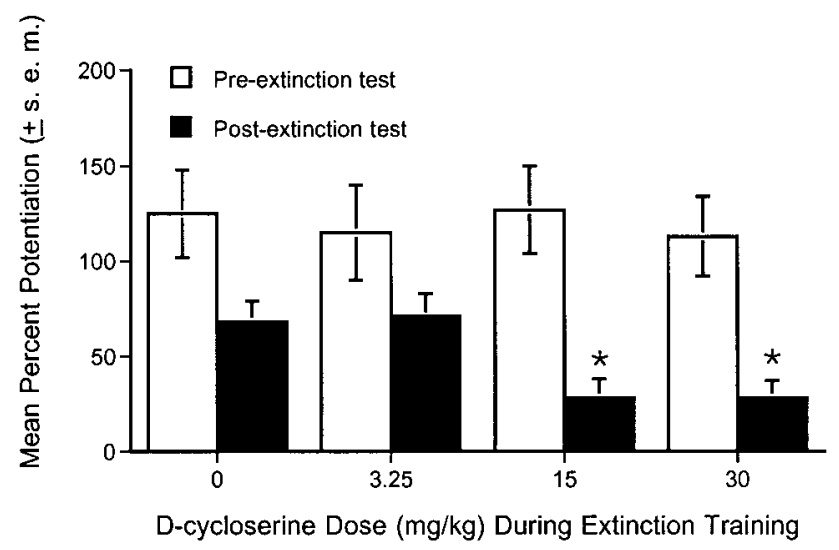

Figure 2. Dose-response function for the effect of DCS on extinction. $A$, Timeline of the behavioral procedures for experiment 2. B, Percent fear-potentiated startle measured $24 \mathrm{hr}$ before and $24 \mathrm{hr}$ after a single session of extinction training in rats injected with saline or DCS $(3.25,15$, or $30 \mathrm{mg} / \mathrm{kg}$, i.p.) $30 \mathrm{~min}$ before non-reinforced cue exposure. DCS dose-dependently facilitated extinction learning. ${ }^{*} p<0.05$ versus saline after extinction.

fear-potentiated startle measure described below. After $30 \mathrm{sec}, 20$ additional noise bursts were presented (ISI of $30 \mathrm{sec}$ ). One-half of these were presented in darkness (noise-alone test trial) and one-half were presented $3.2 \mathrm{sec}$ after onset of the $3.7 \mathrm{sec}$ light (light-noise test trial). The order of these two trial types was randomized with the constraint that no two trial types occurred more than twice in a row. Percent fearpotentiated startle was computed as [(startle amplitude on light-noise minus noise-alone trials)/noise-alone trials] $\times 100$. Based on these data, rats were sorted into equal-sized groups such that each group had comparable mean levels of percent fear-potentiated startle. Because the fear-potentiated startle test is itself an extinction procedure (i.e., CS presentations without shock), and because we wanted to minimize any incidental extinction before explicit extinction training with drug, a minimal number of CS presentations were used in this test compared with the more lengthy postextinction test described below. However, we have found that this abbreviated test is adequate for matching rats into different groups with comparable levels of fear-potentiated startle.

Extinction training. At $24 \mathrm{hr}$ after the pre-extinction test, rats were returned to the test chamber and 5 min later received $303.7 \mathrm{sec}$ light exposures without shock (ISI of $30 \mathrm{sec}$ ). Control rats were placed in the test cages and remained there for the same amount of time as rats in the extinction groups, but did not receive non-reinforced CS presentations. Rats in experiment 1 received one, two, or three sessions of extinction training with a $24 \mathrm{hr}$ interval between each. Rats in all other experiments received a single session of extinction training.

Postextinction test. At $24 \mathrm{hr}$ after the last extinction session, rats were returned to the test chamber and presented 5 min later with $3095 \mathrm{~dB}$ noise bursts, as in the pre-extinction short test, to habituate the startle response to a stable baseline before the noise-alone and light-noise test trials that followed. After $30 \mathrm{sec}, 60$ intermixed noise-alone and lightnoise test trials $(95 \mathrm{~dB}$, ISI of $30 \mathrm{sec})$ were presented. Percent potentiation was calculated from the noise-alone and light-noise test trials as described previously.

\section{Statistics}

ANOVA on percent potentiation scores was the primary statistical measure. Between-group comparisons were also made using two-tailed $t$ tests for independent samples. The criterion for significance for all comparisons was $p<0.05$.

\section{RESULTS}

\section{Experiment 1: parametric evaluation of different amounts of extinction training}

This experiment assessed the effect on fear-potentiated startle of 1,2 , or $3 \mathrm{~d}$ of extinction training. A total of 42 rats were matched into seven groups of six animals, each based on their level of fear-potentiated startle in the pre-extinction test. Beginning $24 \mathrm{hr}$ after the pre-extinction test, rats received 1, 2, or 3 consecutive days of extinction training (30 non-reinforced light presentations per day) or 1,2 , or $3 \mathrm{~d}$ of exposure to the context without extinction training. An additional control group was tested $2 \mathrm{~d}$ after the pre-extinction test without intervening exposures to either context or the visual CS.

Figure $1 B$ shows that after $1 \mathrm{~d}$ of extinction training, fearpotentiated startle was reduced by $\sim 35 \%$ compared with the pre-extinction test. After 2 or $3 \mathrm{~d}$, fear-potentiated startle was reduced by $\sim 90 \%$. A two-way ANOVA with treatment (nonreinforced CS presentations vs context exposure alone) and days (one, two, or three extinction sessions) as between-subjects factors indicated a significant treatment effect $\left(F_{(1,30)}=13.01\right)$ and also a significant treatment $\times$ days interaction $\left(F_{(2,30)}=8.90\right)$. Thus, the reduction of fear-potentiated startle across days was greater in the groups that received non-reinforced CS exposures than in the groups that received context exposure alone. Individ-

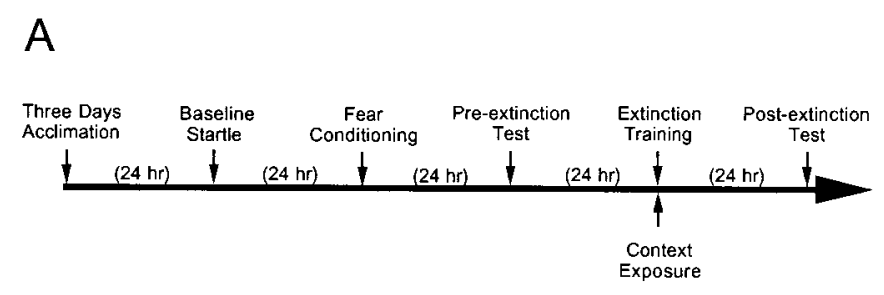

B

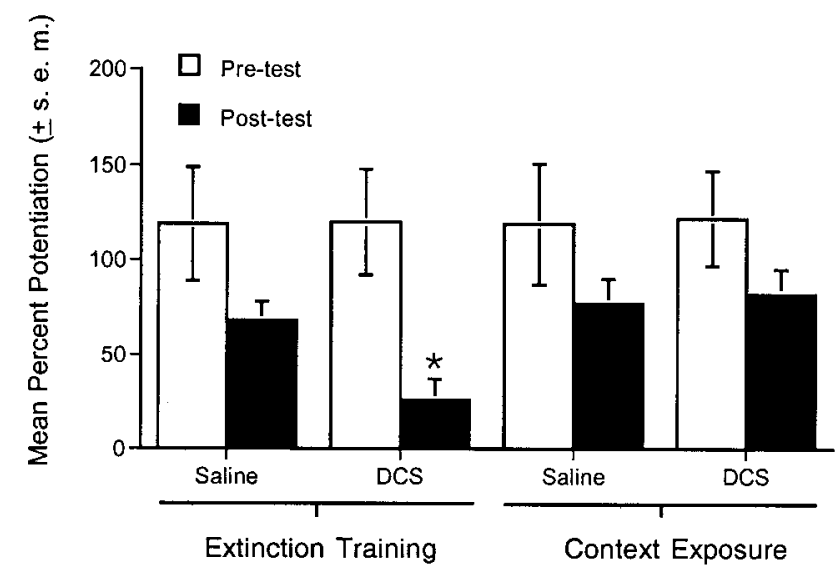

Figure 3. Effect of DCS in nonextinguished rats. $A$, Timeline of the behavioral procedures for experiment 3 . $B$, Percent fear-potentiated startle measured $24 \mathrm{hr}$ before and $24 \mathrm{hr}$ after extinction training. Saline or DCS (15 mg/kg, i.p.) was administered $30 \mathrm{~min}$ before a single session of either extinction training (cue exposure) or context-alone exposure. Fearpotentiated startle was significantly lower in rats that received DCS plus extinction training compared with rats that received saline plus extinction training. Fear-potentiated startle was not appreciably affected by DCS in rats that did not receive extinction training. ${ }^{*} p<0.05$ versus saline plus extinction training. 

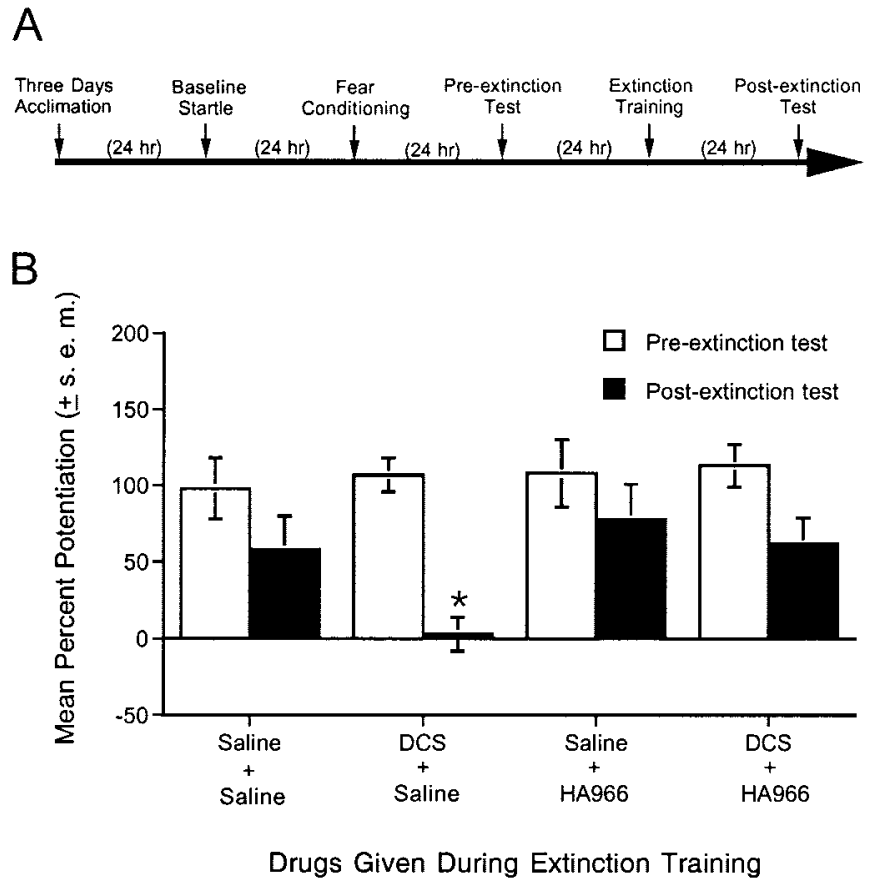

Figure 4. Effect of the strychnine-insensitive glycine-recognition site antagonist HA-966 on extinction and on the facilitation of extinction by DCS. $A$, Timeline of the behavioral procedures for experiment 4. $B$, Percent fear-potentiated startle measured $24 \mathrm{hr}$ before (pre-extinction test) and $24 \mathrm{hr}$ after (postextinction test) extinction training. Saline or HA-966 (6 mg/kg, i.p.) was administered $10 \mathrm{~min}$ before a second injection of saline or DCS, followed 30 min later by a single session of extinction training. HA-966 completely blocked the effects of DCS but did not, on its own, noticeably influence extinction at this dose. ${ }^{*} p<0.05$ versus all other groups.

ual comparisons between non-reinforced CS presentation and context-exposure groups indicated significant differences after 2 $\left(t_{(10)}=3.41\right)$ and $3\left(t_{(10)}=6.37\right) \mathrm{d}$. Significant differences were found between the nonexposed control group and rats that received $1\left(t_{(10)}=2.30\right), 2\left(t_{(10)}=4.33\right)$, or $3\left(t_{(10)}=4.26\right) \mathrm{d}$ of extinction training.

\section{Experiment 2: dose-response function for the effect of DCS on extinction}

A total of 27 rats were acclimated, tested for baseline startle, fear-conditioned, and tested for fear-potentiated startle as described previously. Rats were then divided into four groups of seven animals each (except for the group receiving $30 \mathrm{mg} / \mathrm{kg}$ DCS, for which $n=6$ ) based on their pre-extinction level of fear-potentiated startle. After $24 \mathrm{hr}$, each rat was injected with either saline or DCS (3.25, 15, or $30 \mathrm{mg} / \mathrm{kg}$, i.p.). After $30 \mathrm{~min}$, rats received a single session of extinction training. A single extinction session was used because the results of experiment 1 indicated that this produced a minimal amount of extinction against which a facilitatory effect of DCS could be detected. After $24 \mathrm{hr}$, rats were tested for fear-potentiated startle without drug injections to evaluate the effect on extinction of the previous drug treatments.

DCS facilitated extinction in a dose-dependent manner (Fig. $2 B)$. ANOVA indicated a significant dose effect $\left(F_{(3,23)}=3.02\right)$ with a significant linear trend $\left(F_{(1,23)}=7.26\right)$. Fear-potentiated startle was significantly lower in rats injected with 15 and 30 $\mathrm{mg} / \mathrm{kg}$ DCS before extinction training $\left(t_{(12)}=2.61\right.$ and $t_{(11)}=$ 2.53 for 15 and $30 \mathrm{mg} / \mathrm{kg}$ vs saline, respectively). Because 15 $\mathrm{mg} / \mathrm{kg}$ DCS produced the maximal enhancing effect, we used this dose in our subsequent experiments.

\section{Experiment 3: effect of DCS in nonextinguished rats}

To test whether the effects of DCS reflected an augmentation of extinction per se or instead reflected a disruption of fearpotentiated startle independent of extinction (e.g., a delayed effect on the expression of fear-potentiated startle $24 \mathrm{hr}$ after drug administration), additional rats were tested with and without extinction training. For this experiment, 28 rats were matched into four groups of seven animals each based on the pretest. After $24 \mathrm{hr}$, each rat was injected with either saline or DCS $(15 \mathrm{mg} / \mathrm{kg})$ and returned to its home cage until being placed in the startle chamber 30 min later. Two groups (one group of saline-injected rats and one group of DCS-injected rats) underwent extinction training. Two other groups (one group of saline-injected rats and one group of DCS-injected rats) were placed into the test chamber but did not receive extinction training. After $24 \mathrm{hr}$, all groups were tested for fear-potentiated startle without drug injections.

Figure $3 B$ shows that fear-potentiated startle in rats receiving DCS plus extinction training was significantly lower than in rats that received saline plus extinction training $\left(t_{(12)}=3.02\right)$. This replicates the principal finding of experiment 2 . The novel finding here is that fear-potentiated startle in rats that received DCS without extinction training was comparable with fear-potentiated startle in rats that received saline without extinction training. Thus, the effect of DCS noted in experiment 2 and replicated here appears to reflect a specific influence on extinction and not
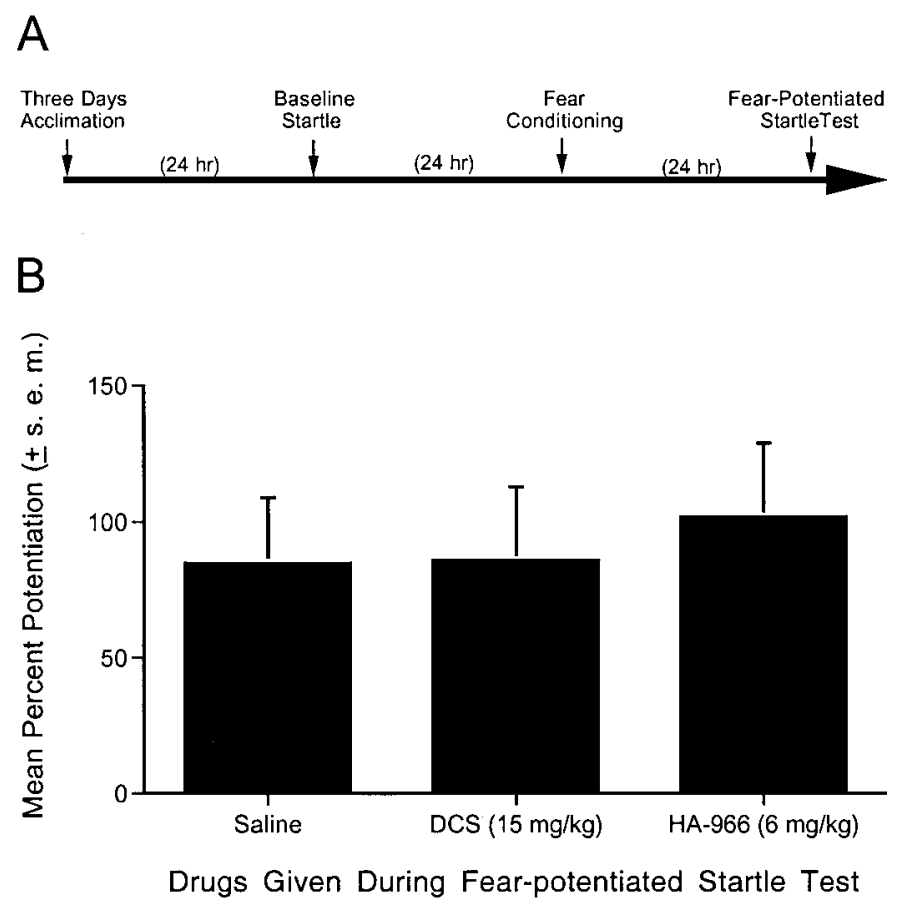

Figure 5. Effect of pretest DCS and HA-966 administration on fearpotentiated startle. $A$, Timeline of the behavioral procedures for experiment 5. B, Percent fear-potentiated startle measured $24 \mathrm{hr}$ after fear conditioning in rats receiving pretest injections of saline, DCS $(15 \mathrm{mg} /$ $\mathrm{kg})$, or HA-966 $(6 \mathrm{mg} / \mathrm{kg})$. Neither drug had any discernible effect on fear-potentiated startle. 

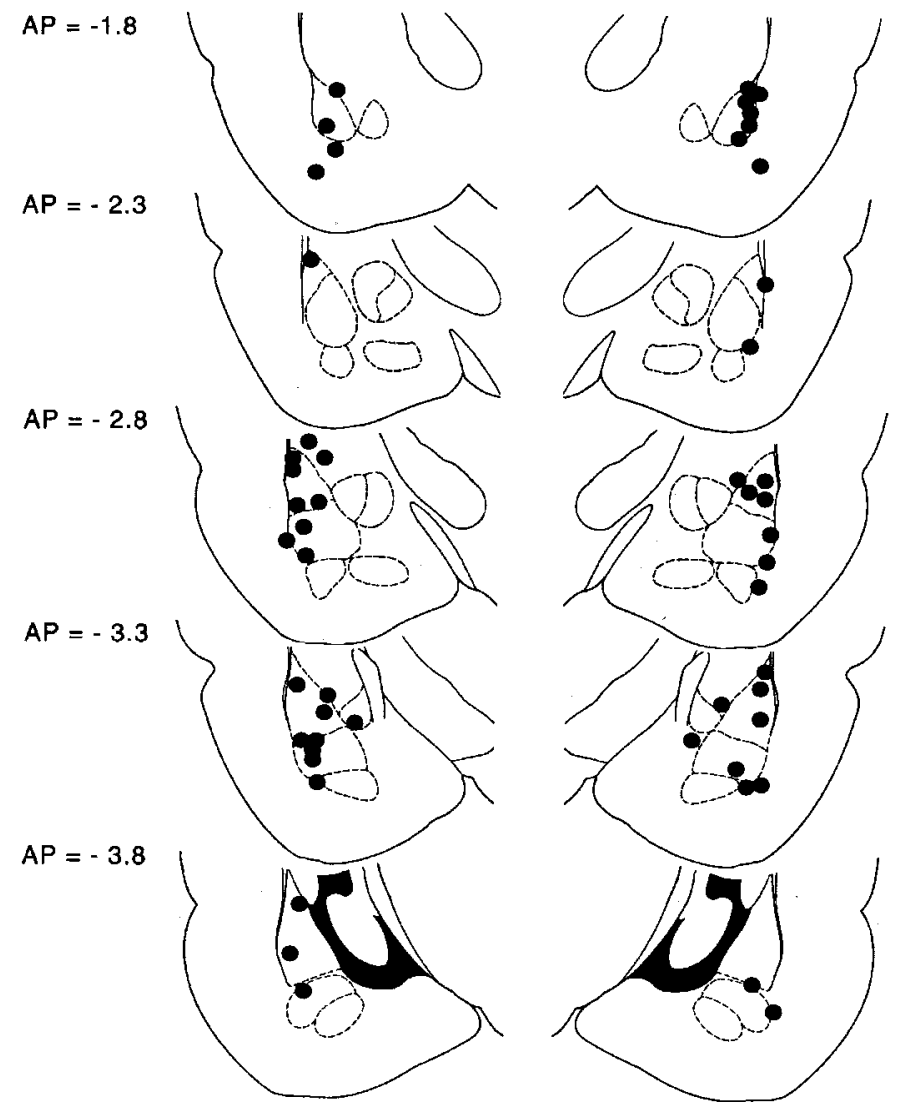

a more general effect on fear-potentiated startle measured $24 \mathrm{hr}$ later in the absence of the drug.

\section{Experiment 4: effect of the strychnine-insensitive glycine-recognition site antagonist HA-966 on extinction and on the facilitation of extinction by DCS}

If DCS facilitates extinction by acting as an agonist at the strychnine-insensitive glycine-recognition site, then the effect of DCS should be blocked by a strychnine-insensitive glycine site antagonist. To test this, 28 rats were matched into four groups of seven animals each based on the pre-extinction test. After $24 \mathrm{hr}$, each rat was injected with either saline or HA-966 $(6 \mathrm{mg} / \mathrm{kg})$ followed $10 \mathrm{~min}$ later by a second injection of either saline or DCS $(15 \mathrm{mg} / \mathrm{kg})$. This dose was chosen based on pilot experiments suggesting that higher doses of HA-966 alone blocked extinction, thereby complicating interpretations of interactive DCS/HA-966 effects. Rats received a single session of extinction training after $30 \mathrm{~min}$ and were tested $24 \mathrm{hr}$ later for fearpotentiated startle with no drug injections.

HA-966 completely blocked the enhancement of extinction produced by DCS but did not in and of itself influence extinction when administered alone (Fig. 4B). Replicating findings from experiments 2 and 3, fear-potentiated startle was significantly lower in rats injected with saline plus DCS compared with rats injected with saline plus saline $\left(t_{(12)}=2.73\right)$. This effect was blocked by HA-966. Fear-potentiated startle in rats injected with HA-966 plus DCS was not significantly different from fearpotentiated startle in rats injected with saline plus saline but was significantly different from fear-potentiated startle in rats injected with saline plus DCS $\left(t_{(12)}=3.35\right)$. Overall, these results suggest

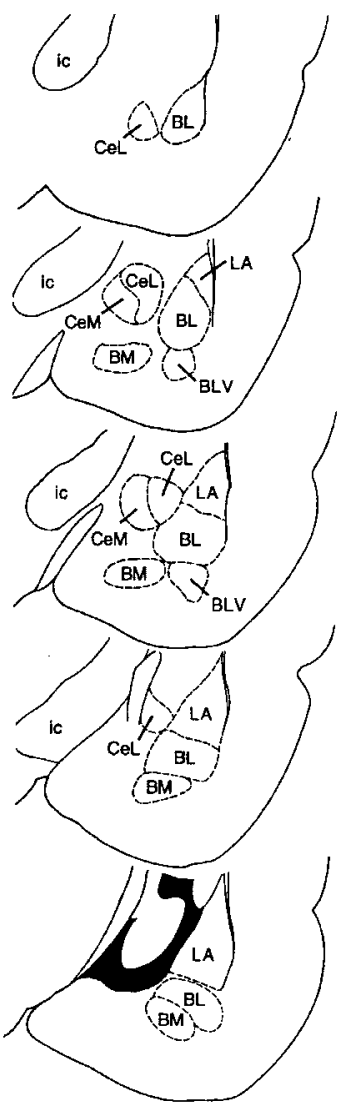

Figure 6. Cannula tip placements transcribed onto atlas plates adapted from Paxinos and Watson (1997). The distance from bregma is indicated to the left; nuclei within the plane of section are identified to the right. $B L$, Basolateral amygdaloid nucleus; $B L V$, basolateral amygdaloid nucleus, ventral part; $B M$, basomedial amygdaloid nucleus; $C e L$, central amygdaloid nucleus, lateral division; $C e M$, central amygdaloid nucleus, medial division; $i c$, internal capsule; $L A$, lateral amygdaloid nucleus.

that the facilitatory effect of DCS on extinction is most likely mediated by the NMDA receptor.

\section{Experiment 5: effect of pretest DCS and HA-966 administration on fear-potentiated startle}

This experiment evaluated whether the effect of DCS or HA966 might be secondary to effects on fear itself or on CS processing. For example, if DCS increases CS-elicited fear, this might facilitate extinction by increasing the discrepancy between what the CS predicts and what actually occurs (Wagner and Rescorla, 1972). If HA-966 interferes with visual processing, this might block the extinction produced by nonreinforced exposures to the visual CS. To evaluate these possibilities, 17 rats (saline, $n=5$; DCS, $n=6$; HA-966, $n=$ 6) were acclimated, tested for baseline startle, and fearconditioned as described previously. After $24 \mathrm{hr}$, rats were injected with saline, DCS (15 mg/ $\mathrm{kg})$, or HA-966 $(6 \mathrm{mg} / \mathrm{kg})$. At 30 (for DCS) or 40 (for HA-966) min after the injections, rats were tested for fear-potentiated startle.

As shown in Figure 5B, neither DCS nor HA-966 significantly influenced fear-potentiated startle when injected before testing. Thus, it is unlikely that these compounds influence extinction by increasing fear or by disrupting CS processing. In fact, a previous study reported a modest anxiolytic effect of both compounds on fear-potentiated startle (Anthony and Nevins, 1993), although at doses higher than those used in the present study. Anxiolytic effects of DCS have also been reported with the elevated plus-maze (Karcz-Kubicha et al., 1997) and, at very high doses, with the Vogel-conflict procedure (Klodzinska and Chojnacka-Wojcik, 2000). 
A

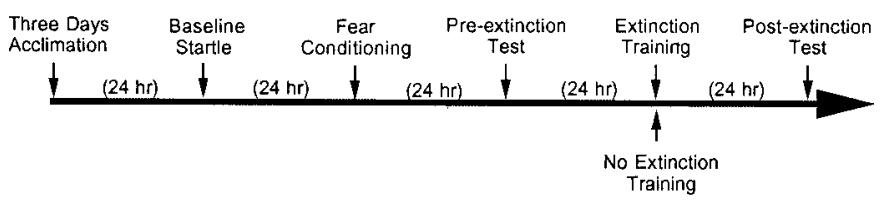

B

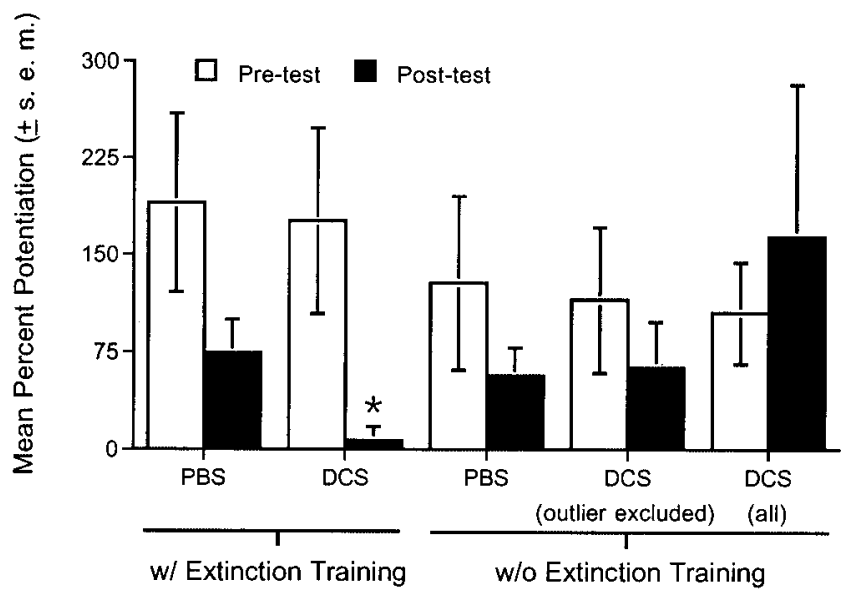

Figure 7. Effect of intra-amygdala DCS infusions. A, Timeline of the behavioral procedures for experiment 3. B, PBS or D-cycloserine (10 $\mu \mathrm{g} / \mathrm{side}$ ) was infused into the amygdala $15 \mathrm{~min}$ before extinction training. Other rats received DCS without extinction training. When tested $24 \mathrm{hr}$ later, fear-potentiated startle was significantly lower in rats that received DCS plus extinction training compared with rats that received PBS plus extinction training. Fear-potentiated startle was not appreciably affected by DCS in rats that did not receive extinction training. For the group that received DCS without extinction training, the mean percent potentiation was calculated with and without data from a single outlier who had an atypically high percent potentiation score. ${ }^{*} p<0.05$ versus all other groups.

\section{Experiment 6: effect of intra-amygdala DCS infusions on extinction}

Previous studies indicate that NMDA receptors in the amygdala play a critical role in the extinction of conditioned fear (Falls et al., 1992; Lee and Kim, 1998). It is possible that the effect of systemically administered DCS reported in the above experiments was mediated by actions at amygdala NMDA receptors. To determine whether the effect of systemically administered DCS would be mimicked by intra-amygdala DCS infusions, 36 rats with intra-amygdala cannulations received fear conditioning, extinction training, and testing for fear-potentiated startle as described previously. Fifteen minutes before being placed into the test chamber for extinction training, rats were infused with either PBS or DCS (10 $\mu \mathrm{g} /$ side). (Preliminary findings suggested a weak effect of $1 \mu \mathrm{g} / \mathrm{side}$ and a more potent effect of $10 \mu \mathrm{g} / \mathrm{side}$.) One group of PBS-infused rats and one group of DCS-infused rats received extinction training. An additional group of PBS-infused rats and an additional group of DCS-infused rats were not placed in the test chamber and did not receive extinction training. Note that this procedure differed from that of experiment 3 , in which control rats received context exposure. Because context exposure constitutes context extinction and because we were particularly concerned in this experiment that intra-amygdala DCS infusions might be associated with neurotoxicity, we wanted to ensure that any loss of fear-potentiated startle after intra-amygdala infusions could unambiguously be attributed to amygdala damage. If, for
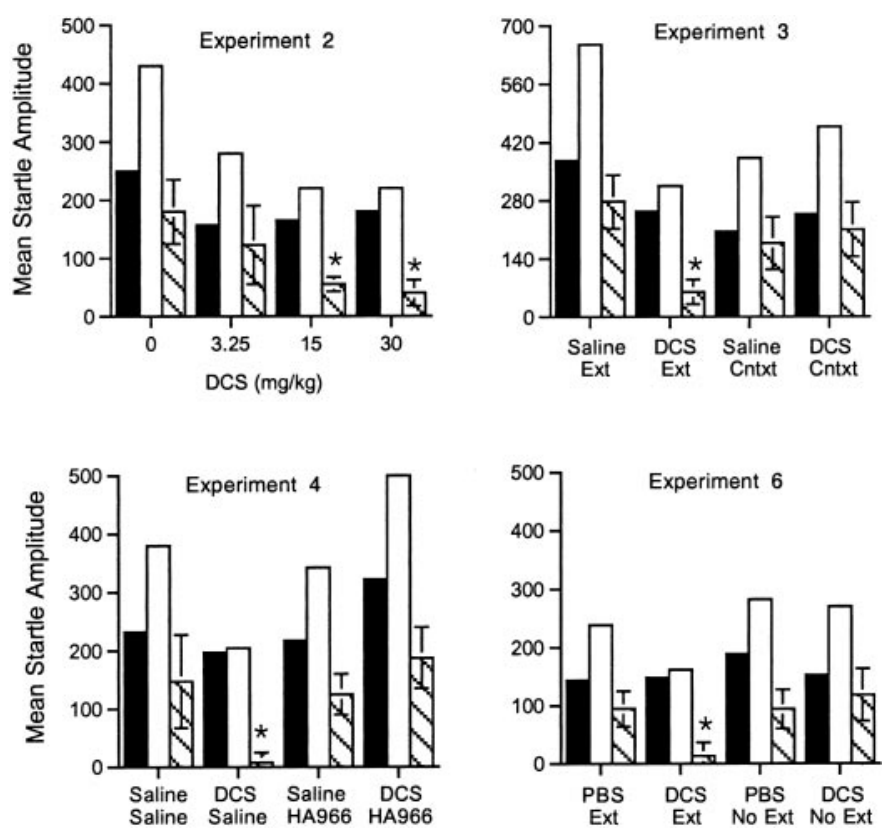

Figure 8. Composite figure showing absolute startle values for all rats receiving drugs before extinction training. Black bars indicate baseline startle amplitude on noise-alone trials; white bars indicate startle amplitude on light-noise trials. The difference between these two (i.e., fearpotentiated startle) is indicated by the striped bars. In no case were significant differences found in baseline startle during the fear-potentiated startle test $24 \mathrm{hr}$ after drug administration. Moreover the statistical results were similar when absolute difference scores (i.e., startle amplitude on light-noise trials minus startle amplitude on noise-alone trials) rather than percent potentiation scores were analyzed. ${ }^{*} p<0.05$ (except Experiment $4, p=0.087$ ) versus leftmost bars.

example, control rats that had received context extinction showed a reduction of CS-elicited fear, it would be unclear whether this was attributable to a DCS-induced lesion or instead to an unintended effect of context extinction on fear to the visual CS. Rats in all groups were tested $24 \mathrm{hr}$ later without drug infusions.

Behavioral data for 10 rats were excluded because the placements for these rats were located outside of the amygdala; as a result $n=9$ for the PBS plus extinction group, $n=9$ for the DCS plus extinction group, $n=4$ for the PBS plus no extinction group, and $n=4$ for the DCS plus no extinction group. Placements for the remaining rats are shown in Figure 6, and the behavioral results are shown in Figure 7. ANOVA indicated a significant treatment $(\mathrm{DCS}$ vs $\mathrm{PBS}) \times$ training (extinction vs no extinction) interaction $\left(F_{(1,22)}=5.05\right)$. Fear-potentiated was significantly lower in rats that received intra-amygdala DCS infusions before extinction training compared with rats that received intraamygdala PBS infusions before extinction training $\left(t_{(16)}=2.49\right)$ and was also significantly lower than in rats that received DCS without extinction training $\left(t_{(11)}=2.36\right)$. Fear-potentiated startle was not significantly different in rats that received PBS versus DCS infusions and no extinction training. The latter result suggests that the effect of DCS in rats that received extinction training is not attributable to neurotoxic DCS effects insofar as this would have disrupted fear-potentiated startle in both groups. In fact, fear-potentiated startle was unusually high in nonextinguished rats that received DCS infusions. This was primarily attributable to a single rat with a percent increase score of $465 \%$. Even with this outlier excluded, fear-potentiated startle was not significantly different in rats that received PBS versus DCS infu- 
sions and no extinction training. As before, however, fearpotentiated startle was significantly lower in rats that received intra-amygdala DCS infusions before extinction training compared with rats that received intra-amygdala DCS infusions without extinction training $\left(t_{(10)}=2.34\right)$.

\section{Effects of DCS and HA-966 on extinction are not attributable to changes in baseline startle}

Figure 8 shows absolute startle values from experiments 2, 3, 4, and 6 (all experiments showing drug effects on extinction). In no experiment did we find significant drug effects on baseline startle when measured in the extinction test $24 \mathrm{hr}$ later. Moreover, the statistical results from analyses of percent potentiation scores were mostly comparable with results obtained using absolute difference scores. Thus, DCS dose-dependently facilitated extinction $\left(F_{(1,24)}=6.03\right.$; experiment 2). Fear-potentiated startle in the DCS plus extinction group was significantly different from fearpotentiated startle in the saline plus extinction group in experiment $3\left(t_{(12)}=3.21\right)$, and fear-potentiated startle was comparable in saline and DCS groups that did not receive extinction training. The difference between fear-potentiated startle in rats injected with DCS plus saline injected versus rats injected with DCS plus HA-966 approached but did not reach significance $\left(t_{(12)}=1.86\right.$; $p=0.087$; experiment 4). Also, fear-potentiated startle was significantly lower in rats that received intra-amygdala DCS infusions before extinction training compared with rats that received PBS infusions $\left(t_{(16)}=2.24\right.$; experiment 6$)$.

\section{DISCUSSION}

The primary finding of this study is that DCS, a partial agonist at the strychnine-insensitive glycine-recognition site on the NMDA receptor complex, facilitates extinction of conditioned fear after either systemic injections (experiments 2, 3, and 4) or intraamygdala infusions (experiment 6). Because DCS reduced fearpotentiated startle only in rats that concurrently received extinction training (experiments 3 and 6), the effects of DCS cannot readily be attributed either to DCS-related neurotoxicity or to anxiolytic drug actions still present $24 \mathrm{hr}$ after drug administration (i.e., during testing). The blockade of the facilitatory influence of DCS on extinction by the glycine-recognition site antagonist HA-966 strongly suggests that the effect of DCS was mediated by interactions with the NMDA receptor (experiment 4). This seems particularly likely insofar as the dose of HA-966 used did not, on its own, increase fear-potentiated startle. Thus, the ability of HA-966 to reverse the effects of DCS on extinction cannot be attributed to a summation of independent facilitatory and disruptive effects, mediated by actions on different systems. The failure of either compound to influence fear-potentiated startle when given before testing suggests that their effects on extinction reflect direct effects on learning processes rather than on CS processing or on fear itself.

As indicated previously, extinction is generally thought to reflect the formation of new inhibitory associations, as opposed to the forgetting of previously formed associations (Pavlov, 1927; Konorski, 1948; Bouton and Bolles, 1985; Falls and Davis, 1995; Davis et al., 2000; Rescorla, 2001). Consistent with this view, the evidence to date suggests that the neural mechanisms, neural circuitry, and pharmacology of excitatory fear conditioning and of conditioned fear extinction are similar. For example, systemic administration of the mitogen-activated protein kinase inhibitor PD98059, as well as intra-amygdala PD98059 infusions, disrupt fear conditioning as assessed with both freezing (Schafe et al., 2000) and shock-motivated avoidance learning (Walz et al., 1999, 2000), respectively, and intra-amygdala PD98059 infusions also disrupt extinction as assessed with fear-potentiated startle (Lu et al., 2001). As noted previously, intra-amygdala infusions of NMDA receptor antagonists block fear conditioning, as assessed with either fear-potentiated startle or freezing, and also block extinction in these same paradigms (Miserendino et al., 1990; Falls et al., 1992; Fanselow and Kim, 1994; Maren et al., 1996; Lee and Kim, 1998; Walker and Davis, 2000).

Although DCS has been shown previously to enhance learning in a variety of learning paradigms (Monahan et al., 1989; Flood et al., 1992; Thompson et al., 1992; Quartermain et al., 1994; Pitkanen et al., 1995; Matsuoka and Aigner, 1996; Pussinen et al., 1997; Land and Riccio, 1999), we are unaware of previous studies showing an enhancement by DCS of extinction learning. In fact, Port and Seybold (1998) reported that DCS retarded extinction of an appetitive instrumental response, and that the NMDA receptor antagonist MK801 enhanced extinction. The latter finding is in contrast to several other studies showing that NMDA receptor antagonists disrupt extinction (Falls et al., 1992; Cox and Westbrook, 1994; Baker and Azorlosa, 1996; Kehoe et al., 1996; Lee and Kim, 1998). The data used to evaluate extinction in Port and Seybold (1998) were collected while animals were still under the influence of DCS (i.e., within-session extinction), and it is possible that effects on performance obscured effects on extinction. It is also possible, although less likely in our view, that the extinction of instrumental responses responds differently to NMDA receptor manipulations than does the extinction of classically conditioned responses.

Recent findings by Tang et al. (1999) are consistent with our results. In that study, conditioned fear extinction was significantly accelerated in transgenic mice overexpressing the NMDA receptor 2B subunit (NR2B) compared with wild-type controls. Overexpression was noted in several forebrain areas, including the amygdala and hippocampus. A facilitatory effect of NR2B overexpression on NMDA receptor-mediated transmission was confirmed in a hippocampal slice preparation. Specifically, Tang et al. (1999) noted significant increases in the peak amplitude and decay time of NMDA receptor-mediated currents and an overall increase in charge transfer through NMDA receptor-associated channels.

Findings implicating amygdala NMDA receptors in both excitatory fear conditioning and conditioned fear extinction are of considerable theoretical interest. Evidence that the extinction of conditioned fear memories might be accelerated by NMDA receptor agonists is also of considerable clinical interest. Many believe that the neural circuitry mediating adaptive fear is closely related if not identical to the neural circuitry mediating clinical fear (e.g., in post-traumatic stress disorder) (Rosen and Schulkin, 1998; Gorman et al., 2000; Bouton et al., 2001). In clinical populations, a reduced ability to extinguish conditioned fear associations might contribute to the persistence of maladaptive fear and may reduce the effectiveness of therapeutic interventions that rely on extinction processes (e.g., systematic desensitization, exposure, and imagery therapies). The results reported here suggest that the effectiveness of these traditional clinical approaches might be facilitated by pharmacological interventions that promote extinction. Clinical trials to test this idea are currently being planned. 


\section{REFERENCES}

Anthony EW, Nevins ME (1993) Anxiolytic-like effects of $N$-methyl-Daspartate-associated glycine receptor ligands in the rat potentiated startle test. Eur J Pharmacol 250:317-324.

Baker JD, Azorlosa JL (1996) The NMDA antagonist MK-801 blocks the extinction of Pavlovian fear conditioning. Behav Neurosci 110:618-620.

Bouton ME, Bolles RC (1985) Context, event-memories, and extinction. Hillsdale, NJ: Lawrence Erlbaum Associates.

Bouton ME, Mineka S, Barlow DH (2001) A modern learning theory perspective on the etiology of panic disorder. Psychol Rev 108:4-32.

Cassella JV, Harty PT, Davis M (1986) Fear conditioning, pre-pulse inhibition, and drug modulation of a short latency startle response measure electromyographically from neck muscles in the rat. Physiol Behav 36:1187-1191.

Cox J, Westbrook RF (1994) The NMDA receptor antagonist MK-801 blocks acquisition and extinction of conditioned hypoalgesia responses in the rat. Q J Exp Psychol B 47B:187-210.

Dadds M, Bovbjerg D, Redd W, Cutmore T (1997) Imagery in human classical conditioning. Psychol Bull 122:89-103.

Davis M (2000) The role of the amygdala in conditioned and unconditioned fear and anxiety. In: The amygdala, Vol 2 (Aggleton JP, ed), pp 213-287. Oxford: Oxford UP.

Davis M, Falls WA, Gewirtz J (2000) Neural systems involved in fear inhibition: extinction and conditioned inhibition. In: Contemporary issues in modeling psychopathology (Myslobodsky M, Weiner I, eds), pp 113-142. Boston: Kluwer Academic.

Emmett MR, Mick SJ, Cler JA, Rao TS, Iyengar S, Wood PL (1991) Actions of D-cycloserine at the $N$-methyl-D-aspartate-associated glycine receptor site in vivo. Neuropharmacology 30:1167-1171.

Falls WA, Davis M (1995) Behavioral and physiological analysis of fear inhibition. In: Neurobiological and clinical consequences of stress: from normal adaptation to PTSD (Friedman MJ, Charney DS, Deutch AY, eds), pp 177-202. Philadelphia: Lippincott-Raven.

Falls WA, Miserendino MJD, Davis M (1992) Extinction of fearpotentiated startle: blockade by infusion of an NMDA antagonist into the amygdala. J Neurosci 12:854-863.

Fanselow M, LeDoux J (1999) Why we think plasticity underlying Pavlovian fear conditioning occurs in the basolateral amygdala. Neuron 23:229-232.

Fanselow MS, Kim JJ (1994) Acquisition of contextual Pavlovian fear conditioning is blocked by application of an NMDA receptor antagonist D,L-2-amino-5-phosphonovaleric acid to the basolateral amygdala. Behav Neurosci 108:210-212.

Flood JF, Morley JE, Lanthorn TH (1992) Effect on memory processing by D-cycloserine, an agonist of the NMDA/glycine receptor. Eur J Pharmacol 221:249-254.

Foa E (2000) Psychosocial treatment of posttraumatic stress disorder. J Clin Psychiatry 61:43-48.

Fyer A (1998) Current approaches to etiology and pathophysiology of specific phobia. Biol Psychiatry 44:1295-1304.

Goff D, Tsai G, Levitt J, Amico E, Manoach D, Schoenfeld D, Hayden D, McCarley R, Coyle J (1999) A placebo-control trial of D-cycloserine added to conventional neuroleptics in patients with schizophrenia. Arch Gen Psychiatry 56:21-27.

Gorman J, Kent J, Sullivan G, Coplan J (2000) Neuroanatomical hypothesis of panic disorder, revised. Am J Psychiatry 157:493-505.

Hamelin SM, Lehmann JC (1995) Effects of putative cognition enhancers on the NMDA receptor by $\left[{ }^{3} \mathrm{H}\right] \mathrm{MK} 801$ binding. Eur J Pharmacol 281:R11-R13.

Hood WF, Compton RP, Monahan JB (1989) D-cycloserine: a ligand for the $N$-methyl-D-aspartate coupled glycine receptor has partial agonist characteristics. Neurosci Lett 98:91-95.

Javitt D, Zylberman I, Zukin S, Heresco-Levy U, Lindenmayer J (1994) Amelioration of negative symptoms in schizophrenia by glycine. Am J Psychiatry 151:1234-1236.

Kapp BS, Wilson A, Pascoe JP, Supple WF, Whalen PJ (1990) A neuroanatomical systems analysis of conditioned bradycardia in the rabbit. In: Neurocomputation and learning: foundations of adaptive networks (Gabriel M, Moore J, eds), pp 55-90. New York: Bradford Books.

Karcz-Kubicha M, Hessa M, Nazar M, Plaznik A, Hartmann S, Parsons CG, Danysz W (1997) Anxiolytic activity of glycine-B antagonists and partial agonists-no relation to intrinsic activity in the patch clamp. Neuropharmacology 36:1355-1367.

Kehoe EJ, Macrae M, Hutchinson CL (1996) MK-801 protects conditioned response from extinction in the rabbit nictitating membrane preparation. Psychobiology 24:127-135.

Klodzinska A, Chojnacka-Wojcik E (2000) Anticonflict effect of the glycine B receptor partial agonist, D-cycloserine, in rats. Pharmacological analysis. Psychopharmacologia 152:224-228.
Konorski J (1948) Conditioned reflexes and neuronal organization. London: Cambridge UP.

Land C, Riccio D (1999) D-cycloserine: effects on long-term retention of a conditioned response and on memory for contextual attributes. Neurobiol Learn Mem 72:158-168.

Lawlor BA, Davis KL (1992) Does modulation of glutamatergic function represent a viable therapeutic strategy in Alzheimer's disease? Biol Psychiatry 31:337-350.

Lee H, Kim J (1998) Amygdalar NMDA receptors are critical for new fear learning in previously fear-conditioned rats. J Neurosci 18:8444-8454.

Loscher W, Wlaz P, Rundfeldt C, Baran H, Honack D (1994) Anticonvulsant effects of the glycine/NMDA receptor ligands D-cycloserine and D-serine but not R-(+)-HA-966 in amygdala-kindled rats. Br J Pharmacol 112:97-106.

Lu KT, Walker DL, Davis M (2001) Mitogen-activated protein kinase cascade in the basolateral nucleus of amygdala is involved in extinction of fear-potentiated startle. J Neurosci 21:RC162:1-5.

Maren S, Aharonov G, Stote D, Fanselow M (1996) $N$-methyl-Daspartate receptors in the basolateral amygdala are required for both acquisition and expression of conditional fear in rats. Behav Neurosci 110:1365-1374.

Matsuoka N, Aigner T (1996) D-cycloserine, a partial agonist at the glycine site coupled to $N$-methyl-D-aspartate receptors, improves visual recognition memory in rhesus monkeys. J Pharmacol Exp Ther 278:891-897.

Miserendino MJD, Sananes CB, Melia KR, Davis M (1990) Blocking of acquisition but not expression of conditioned fear-potentiated startle by NMDA antagonists in the amygdala. Nature 345:716-718.

Monahan JB, Handelman GE, Hood WF, Cordi AA (1989) D-cycloserine, a positive modulator of the $N$-methyl-D-aspartate receptor, enhances performance of learning tasks in rats. Pharmacol Biochem Behav 34:649-653.

Moraes Ferreira VM, Morato GS (1997) D-cycloserine blocks the effect of ethanol and HA-966 in rats tested in the elevated plus-maze. Alcohol Clin Exp Res 21:1638-1642.

Morgan CA, Grillon C, Southwick SM, Davis M, Charney DS (1995) Fear-potentiated startle in post traumatic stress disorder. Biol Psychiatry $38: 378-385$.

Olney JW (1994) New mechanisms of excitatory transmitter neurotoxicity. J Neural Transm Suppl 43:47-51.

Pavlov IP (1927) Conditioned reflexes. Oxford: Oxford UP.

Paxinos G, Watson C (1997) The rat brain in stereotaxic coordinates, Ed 3. New York: Academic.

Pitkanen M, Sirvio J, MacDonald E, Niemi S, Ekonsalo T, Riekkinen P (1995) The effects of D-cycloserine and MK-801 on the performance of rats in two spatial learning and memory tasks. Eur Neuropsychopharmacol 5:457-463.

Port R, Seybold K (1998) Manipulation of NMDA-receptor activity alters extinction of an instrumental response in rats. Physiol Behav 64:391-393.

Priestley T, Kemp JA (1994) Kinetic study of the interactions between the glutamate and glycine recognition sites on the $N$-methyl-D-aspartic acid receptor complex. Mol Pharmacol 46:1191-1196.

Pussinen R, Niememinen S, Koivisto E, Haapalinna A, Riekkinen S, Sirvio J (1997) Enhancement of intermediate-term memory by an $\alpha 1$ agonist or a partial agonist at the glycine site of the NMDA receptor. Neurobiol Learn Mem 67:69-74.

Quartermain D, Mower J, Rafferty MF, Herting RL, Lanthorn TH (1994) Acute but not chronic activation of the NMDA-coupled glycine receptor with D-cycloserine facilitates learning and retention. Eur J Pharmacol 257:7-12.

Rescorla RA (2001) Experimental extinction. In: Handbook of contemporary learning theories (Mowrer RR, Klein S, eds), pp 119-154. Mahwah, NJ: Erlbaum.

Rosen JB, Schulkin J (1998) From normal fear to pathological anxiety. Psychol Rev 105:325-350.

Schafe GE, Atkins CM, Swank MW, Bauer EP, Sweatt JD, LeDoux JE (2000) Activation of ERK/MAP kinase in the amygdala is required for memory consolidation of pavlovian fear conditioning. J Neurosci 20:8177-8187.

Schwartz B, Hashtroudi S, Herting R, Schwartz P, Deutsch S (1996) D-cycloserine enhances implicit memory in Alzheimer patients. Neurology 46:420-424.

Tang YP, Shimizu E, Dube GR, Rampon C, Kerchner GA, Zhuo M, Liu G, Tsien JZ (1999) Genetic enhancement of learning and memory in mice. Nature 401:25-27.

Thompson LT, Moskal JR, Disterhoftt JF (1992) Hippocampusdependent learning facilitated by a monoclonal antibody or D-cycloserine. Nature 359:638-641.

Tsai G, Falk W, Gunther J, Coyle J (1999) Improved cognition in Alz- 
heimer's disease with short-term D-cycloserine treatment. Am J Psychiatry 156:467-469.

Wagner AR, Rescorla RA (1972) Inhibition in pavlovian conditioning: application of a theory. In: Inhibition and learning (Boakes RA, Halliday MS, eds), pp 301-336. London: Academic.

Walker DL, Davis M (2000) Involvement of $N$-methyl-D-aspartate (NMDA) receptors within the amygdala in short- versus long-term memory for fear conditioning as assessed with fear-potentiated startle. Behav Neurosci 114:1019-1033.

Walz R, Roesler R, Barros DM, de Souza MM, Rodriques C, Sant'Anna MK, Quevedo J, Choi HK, Neto WP, De David e Silva TL, Medina JH, Izquierdo I (1999) Effects of post-training infusions of a mitogenactivated protein kinase kinase inhibitor into the hippocampus or entorhinal cortex on short- and long-term retention of inhibitory avoidance. Behav Pharmacol 10:723-730.

Walz R, Roesler R, Quevedo J, Sant'Anna MK, Madruga M, Rodriques C, Gottfried C, Medina JH, Izquierdo I (2000) Time-dependent impairment of inhibitory avoidance retention in rats by posttraining infusion of a mitogen-activated protein kinase kinase inhibitor into cortical and limbic structures. Neurobiol Learn Mem 73:11-20.

Watson GB, Bolanowski MA, Baganoff MP, Deppeler CL, Lanthorn TH (1990) D-cycloserine acts as a partial agonist at the glycine modulatory site of the NMDA receptor expressed in Xenopus oocytes. Brain Res $510: 158-160$

Zarate R, Agras W (1994) Psychosocial treatment of phobia and panic disorders. Psychiatry 57:133-141. 